Journal of Health Promotion and Behavior (2016), 1(2): 128-138

https://doi.org/10.26911/thejhpb.2016.01.02.08

\title{
Decision to Choose Acupuncture Therapy for Degenerative Diseases among the Elderly at Ja'far Medika Hospital, Karanganyar
}

\author{
Purwanto'), Ruben Dharmawan'), Argyo Demartoto3) \\ 1)Masters Program in Public Health, Universitas Sebelas Maret \\ 2)Faculty of Medicine, Universitas Sebelas Maret \\ 3)Faculty of Social and Political Sciences, Universitas Sebelas Maret
}

\begin{abstract}
Background: Aging process results in biological, physical, and mental changes in the elderly. Degenerative diseases are common in the elderly. They can be treated by pharmacologic or non pharmacologic treatment. Acupuncture therapy potentially can be used as a complementary or alternative therapy to treat degenerative diseases in the elderly. This study aimed to investigate factors that determine the decision to choose acupuncture therapy for the degenerative diseases in the elderly at Ja'far Medika Hospital, Karanganyar, Central Java.

SubjectsandMethod: This was a qualitative study with phenomenology approach. This study was conducted at Ja'far Medika Hospital, Karanganyar, Central Java, fromMarch to April 2015. Ten informants were selected for this study by purposive sampling. The data were collected by indepth interview, observation, and document review.They were validated by source triangulation, and analyzed by Miles and Huberman method.

Results: The sample consisted of 5 men and 5 women, aged 53 to 72 years old, with school attainment varying from primary school to university graduate. Job category included farmer, civil servant, and pensioner. The degenerative diseases that were treated by acupuncture therapy including post-stroke, hernia nucleous pulposus, and eyelid disorder. Internal factors that determined the decision to choose acupuncture were motivation to recover, (religious) belief, and boredom to medical service. External factors that determined the decision to choose acupuncture included the quality of service, family support, trust in the therapist, and hospital image. According to the informants, the acupuncture therapy could help recover their health from the degenerative diseases. Most of them used acupuncture as a complementary treatment.

Conclusion: Some internal and external factors determine the decision to choose acupuncture therapy for the degenerative health problem in the elderly. Acupuncture treatment is reported to help recover health in the elderly.
\end{abstract}

Keywords: acupuncture, decision, degenerative disease, elderly

Correspondence:

Purwanto. Masters Program in Public Health, Universitas Sebelas Maret. Jl. Ir. Sutami 36A, Surakarta 57126, Central Java. Email: Purwanto.akp@gmail.com. Mobile: o81393289784.

\section{BACKGROUND}

The process of getting old is one of the consequences of life that cannot be avoided. The aging process will continue without being able to be prevented. Along with that, there will be specific changes in the geriatric group that bring physical and mental changes. This in turn will bring many problems that must be dealt with by the individuals, families, and national and international communities (Tjipto, 2010). According to the 2013 Basic Health Research, the elderly over the age of 60 reached $8.9 \%$ of the population in Indonesia. The population is increasing faster than the population of other age groups as a result of increasing life expectancy and decreasing mortality. The important thing related to 
the increasing population is the need for integrated health care to improve functional capacity and quality of life for the elderly (Wahdini, 2014). The population in the 11 member countries of the World Health Organization (WHO) in the Southeast Asia region of over 6o years is 142 million people and is expected to continue to increase by 3 times in 2050. The number of elderly people people in Indonesia in 2011 was around 24 million or almost 10\% of the population (Yuliati, et al., 2014). The number of elderly people people in Central Java is based on Central Bureau of Statistics (BPS) data of 3,389,300 people (age 60 years and over) or $10.5 \%$ of the total population of Central Java 32,234,600 people (Armiyati, et al., 2014). Of the total population of Karanganyar which amounted to 838,762 people, $11.6 \%$ (97,304 people) were elderly people (Central Bureau of Statistics, Karanganyar Regency, 2013).

Increased number of elderly people people will have an impact on socio-economy in family, community, and in the government. The important economic implication of an increase in population is an increase in the ratio of dependence on the number of elderly people (Old Age Ratio Dependency). Every population of productive age will bear more and more elderly people. This dependence is caused by the condition of many elderly people experiencing physical and psychological setbacks. It is estimated that the rate of dependence of the elderly people in 2015 was $8.74 \%$. This means that as many as 100 productive residents must support 9 elderly people over 65 years old (Armiyati, et al., 2014). The increasing number of elderly people causes problems especially in terms of health and welfare of the elderly. If the problem is not addressed, it will develop into a complex problem in terms of physical, mental, and social. Older people will be very vulnerable to health problems (Saputri and Indrawati, 2011).

The quality of life of the elderly people continues to decline with increasing age. Decreased mental capacity, changes in social roles, dementia, and depression that often affects the elderly people worsens their condition. Not to mention the various degenerative diseases that accompany the elderly's condition that makes them need extra attention from the people around them. Caring for the elderly people is not only limited to physical health care but also to psychological and sociological factors (Siregar et al., 2014).

Handling elderly people degenerative diseases can be done in various ways, either pharmacologically or non-pharmacologically. Non-pharmacological therapy can be an option to overcome problems in elderly people patients. One such non-pharmacological effort is acupuncture. Haryono et al., (2011) stated that acupuncture is a traditional medicine system from China that has been used since several thousand years ago. The theory of Chinese acupuncture treatment is based on the idea that there is a pattern of energy flow (Qi) through the body's meridian system. Disruption in the flow of energy is believed to cause disease in humans. Acupuncture will help restore the pattern of energy flow so that the disease can be cured. Acupuncture in the medical world is based on neuroscience and medical and evidence based principles, so that it can enter into western medical order (Palermo, 2015)

The National Institutes of Health Consensus Panel on Acupuncture stated that acupuncture is useful as a complementary or alternative therapy that can be incorporated into integrated management programs to prevent or reduce the dose of certain drugs (Wahdini, 2014). Acupuncture can be used as a complementary or 
Journal of Health Promotion and Behavior (2016), 1(2): 128-138

https://doi.org/10.26911/thejhpb.2016.01.02.08

alternative therapy to treat pain in musculoskeletal disorders. Kusuma (2014) stated that some complementary therapies are also effective in dealing with depression in the elderly people such as herbal, nutritional, laughter, and bach flower remedy therapy, progressive relaxation, meditation, acupuncture, acupressure, aromatherapy, and reflexology.

Regulation of the Minister of Health of the Republic of Indonesia Number. 1109/ MENKES/PER/IX/2007, said that alternative complementary medicine is a non-conventional treatment aimed at improving the degree of public health including promotive, preventive, curative, and rehabilitative efforts obtained through structured education with high quality, safety and effectiveness based on biomedical science.

Ja'far Medika Karanganyar Hospital is a privately owned hospital in Karanganyar that has excellent acupuncture services. According to patients' data in Acupuncture Clinic at Ja'far Medika Hospital for the period of 1 December 2014 to 10 January 2015, out of a total of 1,468 patients, 306 were over 65 years of age (Noho et al., 2014).

The results of the preliminary study by conducting an initial interview with acupuncture patients in Ja'far Medika Karanganyar Hospital found that acupuncture therapy was one of the preferred alternative treatments. This is due to reduced trust in modern drugs. With acupuncture, the benefits can be felt only with 2-3 times of therapy. In terms of cost, acupuncture is also cheaper than a routine treatment.

A study conducted by Jauhari, et al., (2008) stated that China physician's patients have the belief that China physician has the ability to cure chronic diseases. The patient's motivation to go to China physician arises after the patient has gone to conventional medicine. Patients' motiva- tion to switch treatment to China physician is due to the patient's distrust of conventional medicine. Patients assume that conventional medicine has failed to cure and is uncertain in treating the disease. Also, patients believe that the use of chemical drugs will have an impact on the organs of the body.

Zhenget al., (2013) compared Chinese medicine with cognitive behavioral therapy. The results of the study revealed that Chinese medicine induces changes in behavior and cognition, Chinese medicine therapy does not share two important features in cognitive behavioral therapy, namely the framework of interactions between behavior and cognition and teaching patients how to identify and dispute dysfunctional thoughts. Chinese medicine consultations have features like cognitive behavioral therapy. Qualitative studies show that changes in behavior and cognition after traditional acupuncture treatment occur because of the process of consulting Chinese medicine or the combined effects of acupuncture. Whereas Yang, et al., (2013) stated that many of the effects produced by acupuncture, a holistic approach and potentially having an impact on human disease, are primarily to regulate body balance at the molecular level.

The Health Belief Model (HBM) is a theory of intrapersonal factors that influence health behavior which is then used in the preparation of health programs, both in terms of intervention and preference. Health Belief Model comes from a psychological theory that health behavior depends mainly on the desire to avoid disease and the belief that such actions will prevent or alleviate disease (Barclay et al, 2007).

According to Bandura (in Woolfolk, 2009) cognitive social theory is a theory that provides understanding, prediction, and changes in human behavior through 
interactions between humans, behavior, and environment. According to Bandura (1999), individuals who have high selfefficacy will be very easy in facing challenges. The individual does not feel doubt because he has a belief that is full of his abilities. Individuals will quickly face problems and be able to rise from failure that he experienced. The process of observing and imitating the behavior and attitudes of others as a model is an act of learning. Bandura's theory explains human behavior in the context of continuous reciprocal interaction between cognitive, behavioral and environmental influences around individuals that have a profound effect on social learning patterns. The purpose of this study was to determine the reasons for choosing acupuncture therapy for degenerative diseases in the elderly people at Ja'far Medika Karanganyar General Hospital

\section{SUBJECTS AND METHOD}

This study was a qualitative descriptive study with a phenomenological approach. The study was conducted at Ja'far Medika Karanganyar Hospital from March until April 2015. The sampling technique was purposive sampling method with 10 informants. The technique of collecting data was in-depth interviews, observations, and document studies. Data analysis used data analysis techniques according to Miles and Huberman which included data reduction, data presentation, and withdrawal and testing conclusions. Data validation used was source triangulation.

\section{RESULTS}

The informants were 5 men and 5 women who were elderly people patients, family of the patients, acupuncture therapists, and doctors at the Ja'far Medika Karanganyar
Hospital. The age range of the informants was 23-72 years with elementary, middle, high school, diploma and bachelor.

Internal factors underlying the selection of acupuncture therapy for degenerative diseases in the elderly

Internal factors which underlied in choosing acupuncture therapy for degenerative diseases in the elderly people were motivation to recover, belief (religion), and saturation of medical services.

Motivation was the power or capacity of the elderly people with degenerative diseases to take decisions to do acupuncture so that they could encourage, generate, mobilize, motivate, run and control elderly people and submit to the act of healing or recovering and free from a disease that had suffered.

The values and beliefs of the elderly people in making a decision to do acupuncture therapy were the basic beliefs used by the elderly people to motivate themselves in choosing acupuncture therapy. Patients have confidence that acupuncture therapy was a factor that influences their ability to do therapy.

Another factor that affected the elderly people to do therapy was the saturation of medical services. Prolonged treatment caused people to get bored and try to find other alternative treatments that speed up the healing process. Acupuncture therapy is an alternative healing therapy for degenerative diseases in the elderly people that combine the eastern and western treatment models.

External factors underlying the selection of acupuncture therapy for degenerative diseases in the elderly

External factors that support elderly people people in choosing acupuncture therapy were quality of service, family support, trust in others, hospital image, and applicable regulatory factors. 
Journal of Health Promotion and Behavior (2016), 1(2): 128-138

https://doi.org/10.26911/thejhpb.2016.01.02.08

Quality of service became an important aspect of a hospital. The quality of services provided in a hospital was closely related to the patients' satisfaction as hospital consumers. Management and health personnel provided the best service to patients so that patients were satisfied with the acupuncture services provided.

Family support was a form of interpersonal relationships given by the family to patients in the form of attention in accompanying the therapeutic process and the cost of care for the elderly. Family was a very influential factor in determining beliefs and values and can also determine the treatment program that was acceptable to them. Families also provided support and made decisions regarding the care of family members with sickness. The existence of family support would affect the elderly people to do acupuncture therapy.

Trust in other people was one of the social factors that underlied the occurrence of social interaction, namely suggestion that was a giving view or influence by someone to someone else in a certain way so that the person followed that view / influence without thinking long. The factor that influenced the elderly people in making decisions for acupuncture therapy was the presence of trust in others.

Hospital images had an impact on patients' attitudes and behavior towards hospitals. The success of the Ja'far Medika Karanganyar Hospital in shaping the image in the community was influenced by several factors such as the history of the hospital, the completeness of facilities and infrastructure, and the success in providing services to patients. The image appeared based on the knowledge and positive information received by the patient on the hospital including the services provided by the hospital, complete medical equipment, and the quality of human resources (doctors and acupuncture therapists).

Elderly patients, patients' families, health workers and hospital management considered the legal aspects of acupuncture services chosen by patients and that given by hospitals.

Acupuncture had an important role related to physical theraphy, especially in dealing with degenerative diseases in the elderly people to relieve pain, speed up recovery of muscle movements, and control the emotions of patients who would benefit the patients and could increase patients' confidence in acupuncture therapists.

\section{DISCUSSION}

The results in this study include internal factors, external factors, and the role of acupuncture on the recovery of health of elderly patients with degenerative diseases, so patients and families decided to choose acupuncture therapy at Ja'far Medika Karanganyar Hospital.

According to Schiffman and Kanuk (2007), decision making can be seen as a system of inputs, processes, and outputs. External factors that can be an input and influence the decision-making process are socio-cultural environments such as family, social class, information and commercial sources, culture, and sub-culture. This process begins with the introduction of needs by patients, followed by information seeking, and alternative evaluation. Output is post-decision making behavior that includes evaluation after decision making.

Elderly people who have a high motivation to heal will always think that he will soon recover from his illness and the patient is also sure that the surrounding conditions or the surrounding environment also influence they to immediately recover from his illness. These results support previous study from Kamaluddin (2010) 
which states that decision making for cupping therapy is the client's desire to recover. Sobur (2005), defining motivation as a more general term that refers to the whole process of movement, including situations that encourage, impulse that arises in the individual, behavior caused, and the purpose or end of movement or action. Therefore, it can also be said that motivation means arousing a motive, arousing the power of movement, moving a person or self to do something, doing acupuncture therapy to cure degenerative diseases experienced by the elderly people. This motivation is manifested in the values, interests, and concern for one's health (Kitko and Hupcey, 2008).

The belief factor in this case is that religion has an influence in the choice of acupuncture therapy decisions in dealing with degenerative diseases in the elderly. Religion has an influence in managing patients. Management decisions that will be chosen will certainly be considered by patients based on the teachings of their religion. This supports the study of Vitell et al., (2006) which stated that trust in God is accompanied by a commitment to follow the principles believed to be established by God. The idea that one's religiosity (religiosity) can influence an individual's judgment, beliefs and behavior in various situations, will appear to be intuitive (Singh, 2005). Religiosity has a good influence on human attitudes and behavior (Weaver and Agle, 2002).

Delener (1994), also revealed that religiosity is an important value in the cognitive structure of individuals that can influence individual behavior. The patient's perception of the condition of the disease and treatment also has an influence, especially in terms of patient medication compliance. Such patients dominantly believe that this is where the disease can be cured.
These results support the study from Varghese (2004) which stated that the effectiveness of alternative medicine is a very influential reason in choosing alternative medicine. One thing is said to be successful if it brings results or changes in the expected direction. Jauhari et al. (2008), in his study also stated that patients have the belief that China physician has the ability to treat chronic diseases.

Elderly patients choose to use acupuncture therapy because of the saturation of medical services. This result is in accordance with the statement from Agusmarni (2012), which stated that the factor of saturation of medical services is because the treatment process is too long causes sufferers to get bored and try to find other alternative treatment that accelerate the healing process.

The same thing was also revealed by Jauhari et al. (2008), that the patient's motivation to go to China physiccian arose after the patient went to conventional medicine, this was because of the patient's distrust of conventional medicine. Patients assume that conventional medicine in treating the disease has failed / uncertain, and the patient's belief that the use of chemical drugs will have an impact on the organs of the body.

The service factor provided by doctors and employees of Ja'far Medika Hospital has made the elderly people to do acupuncture therapy. Elderly people stated that the services provided by doctors and nurses at Ja'far Medika Hospital in Karanganyar are good, this is because the hospital management also instructs all employees to be friendly to patients. These results indicate that service is indeed an important aspect of a hospital. These results support the study of Bishop and Lewith (2013) who stated that there are four different processes for patients in deciding to try 
Journal of Health Promotion and Behavior (2016), 1(2): 128-138

https://doi.org/10.26911/thejhpb.2016.01.02.08

professional acupuncture for health care in this process is to provide support, advice, and improve the general familiarity of people with acupuncture.

Irmawati and Kurniasari (2010), in their study showed that service quality has an effect on patient satisfaction. Satisfaction of the elderly people in doing acupuncture therapy is closely related to the quality of services provided by the hospital.

Families influence the decision of the elderly people to do acupuncture therapy; in this case the family is in charge of conveying information about the existence of acupuncture therapy that can help cure degenerative diseases experienced by the elderly people. The existence of family support for the elderly people will have a positive influence on physical and psychological well-being. This is relevant to previous study from Kamaluddin (2010) which stated that the decision making for cupping therapy is family support. Bishop and Lewith (2013) stated that the decision process to try acupuncture id influenced by the family.

Setiadi (2008) stated that everyone is obliged to participate in maintaining and improving the health status of individuals, families and the environment.

Other people's beliefs are one of the social functions. These results support the study from Kamaluddin (2010), which stated that one of the factors that influence cupping therapy is social factors. The social process according to Mubarak (2009), is a way of relating people and social groups that meet each other. Varghese (2004), stated that social influence is indeed very complex, one of which is the influence of others or the suggestion of friends who have reasons for choosing alternative therapies. According to Maramis (2006), this is due to informational influences, information obtained from other people is accepted as a fact, so that these influences can influence the behavior of people who are around it.

The results of the study showed that the image of the hospital in making decisions for the elderly people to do acupuncture therapy, where the image of the hospital can be seen from the existence of facilities and the presence of figures in the hospital. In this case there is an experienced acupuncture therapist. According to study from Jauhari, et al., (2008), the trigger factor for patients seeking treatment for China physician is due to experience. Bishop and Lewith (2013), in his study also stated that patients decided to try acupuncture because the acupuncturist and a health care professional that can provide support, advice, and improve general familiarity with acupuncture.

The legal factor in the aspect of a health service contributes to the community to choose and use the desired health services. From the results of interviews with informants, it was shown that clients in Ja'far Medika Hospital fully believed that acupuncture therapy performed in Ja'far Medika Hospital was carried out by professional practitioners, which meant that it was carried out by someone who was competent in the field of acupuncture through formal education. Acupuncturists as alternative complementary medicine personnel are in accordance with the Minister of Health Regulation on the Implementation of Alternative-Complementary Medicine in Health Care Facilities. This is in accordance with the definition of alternative kompelemter treatment, namely nonconventional medicine which is intended to improve the degree of public health which includes promofif, preventive, curative, and rehabilitative efforts obtained through structured education with high quality, 
safety, and effectiveness based on biomedical science, which has not been accepted in conventional medicine $(\mathrm{MOH}$, 2007).

The results of this study also show that acupuncture therapy helps patients get improved health conditions. This shows that the effectiveness of alternative medicine is a very influential reason for choosing alternative medicine. The results of this study support the study from Haryatmo (2012) which stated that acupuncture techniques are able to improve the improvement of balance, mobility, daily activities, and quality of life which is characterized by increased muscle strength, which is done by regular acupuncture treatment techniques by patients.

Turana (2003), stated that alternative treatment is a form of medical treatment that uses methods, tools, or materials that are not included in the standards of modern medical treatment (standard medical services) and are used as an alternative or complement to modern medical treatment.

In this study it was also found that in the process of acupuncture therapy services in Ja'far Medika Hospital it was not a single therapy but a combination therapy with medical treatmen that the physiotherapist's actions were carried out collaboratively. This is in line with the explanation of Shi Xuemin (2006), which stated that comprehensive combination therapy is needed to achieve an optimal recovery of the health condition of post stroke patients.

Health Belief Model (HBM) which explains that changes in health behavior are based on rational judgments that are balanced between obstacles and benefits of action. This can be seen from the results of interviews with informants who stated that they had a great motivation and desire to recover from their illness even though they had to travel far, routine therapy, and paid for the costs of acupuncture therapy and finally got the expected therapeutic results. Munro, et al. (2007), stated that demographic and sociopsychological factors are variables that influence the perception of susceptibility to a disease in a person and changes in behavior to maintain their health. Social Cognitive Theory from Bandura (1999) provided an understanding that predictions, and changes in human behavior occur through interactions between humans, behavior, and environment.

Elderly people and the family who chose acupuncture therapy at Ja'far Medika Karanganyar Hospital were a form of behavioral change that occurred because of the interaction of patients, families and the social environment of the community where they lived related to their health care behavior by choosing acupuncture therapy at Ja'far Umun Umar Hospital. .

The decision to choose acupuncture therapy in the elderly people with degenerative diseases is based on internal factors including motivation to recover, confidence, and saturation of standard (medical) treatment and strengthened by external factors including service quality, family support, trust in others, hospital image, and applicable laws and regulations. Acupuncture therapy plays a role in improving the health condition of the elderly people and provides better results with a combination and collaboration with other therapies and treatments.

\section{REFERENCE}

Agusmarni S (2012). Gambaran Healht belief model pada individu penderita diabetes yang meng gunakan pengobatan medis dan alternative. http:- 
Journal of Health Promotion and Behavior (2016), 1(2): 128-138

https://doi.org/10.26911/thejhpb.2016.01.02.08

//www.Satuharapan.Com.Retrieved

February 12, 2015

Armiyati Y, Soesanto E, Hartiti T (2014). Pemberdayaan kader posbindu lansia sebagai upaya peningkatan kualitas hidup lansia di Desa Kangkung Demak. Prosiding Hasil-Hasil Seminar Nasional. Universitas Muhammadiyah Semarang.

Badan Pusat Statistik Kabupaten Karanganyar (2013). Karanganyar Dalam Angka 2013. www. karanganyarkab.go.id/wp-conten2014/o5/Karanganyar-Dalam-Angka-2013.pdf. Retrieved February 13, 2015.

Bandura A (1999). Social Cognitive Theory: An Agentic Perspective. Asian Journal of Social Psychology. 2: 21-41.

Barclay TR, Hinkin CH, Castellon SA, Mason, KI, Marion SD, Levine AJ, Durvasula RS (2007). Age-associated predictors of medication adherence in HIV-positive adults: health beliefs, self-efficacy, and neurocognitive status. Health Psychol. 26(1): 40-49. https://doi.org/10.1037/0278-6133.26.1.40

Bishop FL, Lewith GT (2013). Patients preconceptions of acupuncture: a qualitative study exploring the decisions patients make when seeking acupuncture. BMC Complementary \& Alternative Medicine. 13(102). doi: 10.1186/1472-6882-13-102.

Delener N (1994). Religious contrasts in consumer decision behaviour patterns: Their dimensions and marketing implications. Journal of Marketing. 28(2): 36-53. https://doi.org/10.1108/03090569410062023

Departemen Kesehatan Republik Indonesia (2007). Peraturan Menteri Kesehatan Nomor 1109 Tahun 2007 tentang Penyelenggaraan Pengobatan Komplementer-Alternatif.
Fishbein M, Ajzen I (2005). Belief, Attitude, Intention, and Behavior: An Introduction to Theory and Research. Reading, Mass: Addi son-Wesley.

Harapan S (2009). Terapi alternatif makin marak. Retrieved from http://www.belajarpijat.com. Pada 17 Februari 2015.

Haryatmo (2012). Manfaat akupunktur pada penderita stroke hemor ragik terhadap peningkatan keku atan otot anggota gerak atas. Surakarta: Program Studi S1 Fisioterapi Fakultas Ilmu Kesehatan Universitas Muhammadiyah Surakarta.

Haryono DC, Andreanus A, Soemardji, Fanty F (2011). Peranan terapi akupunktur "GI" pada penderita stroke. JKM. 10 (2):142-150

Irmawati, Kurniasari, Ria (2010). Pengaruh kualitas pelayanan jasa terhadap keputusan pasien berobat rawat inap di RSUD Moewardi Jebres. Benefit: Jurnal Manajemen dan Bisnis15(1):1-16.

Jauhari AH, Utami MS, Padmawati RS (2008). Motivasi dan kepercayaan pasien untuk berobat ke Sinse. Berita Kedokteran Masyarakat. 24(1).

Kamaluddin (2010). Pengalaman pasien hipertensi yang menjalani terapi alternatif komplementer bekam di Kabupaten Banyumas. Tesis. Jakarta: Fakultas Kedokteran Universitas Indonesia Program Studi Akupunktur Medik.

Kitko L, Hupcey JE (2008). Factors that influences health-seeking behaviours of patients experiencing acuate stroke. Journal of Neouroscience Nursing. 40(6): 333-340. https://doi.org/10.1097/01376517-200812000-00004.

Maramis WF (2006). Catatan Ilmu Kedokteran Jiwa. Surabaya: Airlangga University Press. 
Mubarak WI (2009). Ilmu Keperawatan Komunitas; Konsep dan Aplikasi. Jakarta: Salemba Medika.

Munro S, Lewin S, Swart T, Volmink J (2007). A review of health behaviour theories: how useful are these for developing interventions to promote long-term medication adherence for TB and HIV/AIDS?. BMC Public Health. 7(104): 1-16. https://doi.org/10.1186/1471-2458-7-104

Noho Z, Sadewo B, Astuti KD, Kurniawati R (2015). Laporan praktik kerja lapangan di rumah sakit umum Ja'far Medika Karanganyar. Prodi D-III Akupunktur Jurusan Akupunktur Poltekkes Kemenkes Surakarta.

Palermo J (2015). How Does Acupuncture Works.http://www.medicinenet.com/ acupuncture/page3.htm. Retrieved May 28, 2015

Peraturan Menteri Kesehatan Republik Indonesia Nomor 1186/ Menkes/Per/XI/1996 Tentang Pemanfaat an Akupunktur di Sarana Pelayan an Kesehatan

Peraturan Menteri Kesehatan Republik Indonesia Nomor.1109/MENKES/PER/IX/2007. Tentang Pengobatan komplementer dan Alternatif.

Saputri MAW, Indrawati ES (2011). Hubungan antara dukungan sosial dengan depresi pada lanjut usia yang tinggal di panti wreda Wening Wardoyo Jawa Tengah. Jurnal Psikologi Undip. 9(1): 65-72.

Schiffman, Kanuk (2007). Perilaku Konsumen. Jakarta: PT. Indeks.

Setiadi (2008). Keperawatan Keluarga. Jakarta : EGC.

Shi Xuemin (2006). Acupuncture and Moxibustion. Beijing: Higher Educatio Press
Singh A (2005). Molecular Basis of PlantSymbiotic Fungi Interaction: AnOverview. Scientific World 5:115 - 131

Siregar SF, Arma AJ, Lubis RM (2014). Perbandingan kualitas hidup lanjut usia yang tinggal di panti jompo dengan yang tinggal di rumah di Kabupaten Tapanuli Selatan Tahun 2013. Medan: Fakultas Kesehatan Masyarakat Universitas Sumatera Utara.

Sobur A (2006). Psikologi Umum. Bandung: Pustaka Setia.

Tjipto BW (2010). Kajian terapi akupunktur terhadap kadar hormon testosteron pria usia lanjut. Buletin Penelitian Sistem Kesehatan. 13(1): 92-99.

Turana Y (2003). Merawat Demensia, RS. Atmajaya: Artikel.

Varghese CT (2004). Is Patient's Preference for Medical Care Changing?. Med J Armed Forces India. 6(1): 115-116. https://dx.doi.org/10.1016\%2FSo3771237(05)80003-6.

Vitell SJ, Paolillo JGP, Singh J (2006). The role of money and religiosity in determiningconsumers' ethical beliefs. Journal of Business Ethics. 6(4):117124. Doi: 10.1007/s10551-005-1901-X

Wahdini S (2014). Peran Akupunktur dalam Penatalaksanaan Pasien Geriatri. e-Journal Kedokteran Universitas Indonesia2 (2): 379-384.

Weaver GR, Agle BR (2002). Religiousity and Behavior in Organizations: A Symbolic Inter actionist Perspective. Academy of Management Review 27(1): 77-97.

Yang JW, Li QQ, Li F, Fu QN, Zeng XH, Liu CZ (2013). The holistic effects of acupuncture treatment. Evidence-Based Complementary and Alternative Medicine: 1-10. http://dx.doi.org/10.1155/2014/739708

Yuliati A, Baroya N, Ririanty M(2014). Perbedaan kualitas hidup lansia yang 
Journal of Health Promotion and Behavior (2016), 1(2): 128-138

https://doi.org/10.26911/thejhpb.2016.01.02.08

tinggal di komunitas dengan di pelayanan sosial lanjut usia. e-Jurnal Pustaka Kesehatan. 2(1): 87-94.

Zheng Z, Paterson C, Yap K (2013). Does Chinese medicine consultation share features and effects of cognitivebehavioural therapy? Using traditional acupuncture as an example. Australian Journal of Acupuncture and Chinese Medicine. 8(2): 6-15. 